\title{
Prevalence of Dyslipidemia in Patients with Acute Coronary Syndrome Admitted at Tertiary Care Hospital in Nepal: A Descriptive Cross- sectional Study
}

\author{
Sahadeb Prasad Dhungana, ${ }^{1}$ Arun Kumar Mahato, ${ }^{2}$ Rinku Ghimire, ${ }^{3}$ Rupesh Kumar Shreewastav ${ }^{4}$ \\ 'Department of Internal Medicine and cardiology unit, Nobel Medical College Teaching Hospital, Biratnagar, Nepal, \\ ${ }^{2}$ Department of Internal Medicine, Nobel Medical College Teaching Hospital, Biratnagar, Nepal, ${ }^{3}$ Department of \\ Pharmacology, Nobel Medical College Teaching Hospital, Biratnagar, Nepal, 'Department of Biochemistry, Nobel Medical \\ College Teaching Hospital, Biratnagar, Nepal.
}

\section{ABSTRACT}

Introduction: Dyslipidemia is one of the major risk factors for acute coronary syndrome. Dyslipidemia with an increase in total cholesterol, low-density lipoprotein cholesterol, triglycerides and decrease in high-density lipoprotein cholesterol is one of the major risk factors for the acute coronary syndrome and alone account for more than $50 \%$ of population attributable risk. This study was conducted to find out the prevalence of dyslipidemia.

Methods: This descriptive cross-sectional study was conducted in 105 patients admitted at the tertiary care center with a diagnosis of acute coronary syndrome from July 2018 to March 2019 after approval from the institutional review committee (Ref no. 205/2018). Fasting serum lipid profile was obtained within 24 hours of hospitalization with the convenient sampling method. Data were analyzed with the help of the Statistical Package for Social Sciences version 20. Point estimation at 95\% Confidence interval was calculated along with frequency and proportion for binary data.

Results: Out of 105 people, dyslipidemia was present in 51 (48.6\%). The mean age of the participants was $59.19 \pm 12.69$ years. The majority 81 (77.1\%) were male. The mean total cholesterol, triglycerides, low-density lipoprotein cholesterol, and high-density lipoprotein cholesterol were $183.43 \pm 35.9 \mathrm{mg} /$ $\mathrm{dl}, 140.59 \pm 46.83 \mathrm{mg} / \mathrm{dl}, 109.9 \pm 26.38 \mathrm{mg} / \mathrm{dl}$ and $41.17 \pm 4.78 \mathrm{mg} / \mathrm{dl}$ respectively. High total cholesterol and triglyceride were found in 34 (32.4\%) each, low high-density lipoprotein in 31 (29.5\%) and high low-density lipoprotein in $22(21 \%)$. It was present in $8(42.1 \%)$ underweight, $24(40.7 \%)$ normal weight and $19(70.4 \%)$ overweight patients. It was present in 20 (60.6\%) diabetics, $34(48.6 \%)$ hypertensives, $5(45.5 \%)$ smokers and $2(33.3 \%)$ with a family history of coronary artery disease.

Conclusions: Dyslipidemia is a significant risk factor in patients with acute coronary syndrome and commonly associated with other risk factors. Careful attention to its management may help to reduce further events.

Keywords: acute coronary syndrome; dyslipidemia; prevalence.

\section{INTRODUCTION}

Dyslipidemia with an increase in total cholesterol (TC), low-density lipoprotein cholesterol (LDL-C), triglycerides (TG) and decrease in high-density lipoprotein cholesterol (HDL-C) is one of the major risk factors for the acute coronary syndrome $(A C S)^{1}$ and alone account for more than $50 \%$ of population attributable risk. ${ }^{2}$ Untreated dyslipidemia is the strongest predictor of in-hospital death. ${ }^{3}$

There is an agreement that the measurement of TC

Correspondence: Dr. Sahadeb Prasad Dhungana, Department of Internal Medicine and cardiology unit, Nobel Medical College Teaching Hospital, Biratnagar, Nepal. Email: drsadhu@gmail.com, Phone: +977. 9861773031. 
within the first 24 hours of myocardial infarction (MI) reflects its habitual value. ${ }^{4,5}$ Therefore, the guidelines suggest that the lipid profile be measured within that time interval. ${ }^{6}$ Dyslipidemia is an independent and modifiable risk factor that is common in our population. It remains unrecognized until detected during the first presentation with ACS.

So, this study aimed to find out the prevalence of dyslipidemia within 24 hours of admission with ACS and thereby help to the early classification of dyslipidemia and select the appropriate therapy.

\section{METHODS}

This is a descriptive cross-sectional study, which was conducted on 105 admitted patients diagnosed with ACS at Nobel Medical College Teaching Hospital from July 2018 to March 2019 after getting the approval from the Institutional review committee (Ref no. 205/2018). All the participants had signed the consent for the study. History and clinical examination were performed as per the pre-structured proforma. All cases above the age of 20 years with a diagnosis of ACS were enrolled by a convenience sampling method. Patients with stable coronary artery disease were excluded. The sample size of 105 was calculated based on the $62 \%$ prevalence of dyslipidemia in patients with ACS in the study conducted at another tertiary care hospital in $\mathrm{Nepal}^{7}$ by using formula

$\mathrm{n}=\mathrm{Z}^{2} \times \mathrm{p} \times \mathrm{q} / \mathrm{e}^{2}$

$=(1.96)^{2} \times 62 \times 38 /(9.3)^{2}=3.84 \times 2356 / 86.49$

$=104.6$

Where,

$\mathrm{n}=$ required sample size

$p=$ prevalence of condition $(62 \%)^{7}$

$q=1-p$

$\mathrm{e}=$ margin of error $(15 \%$ of $62=9.3)$

Where, the $5 \%$ level of significance $(Z=1.96)$ and $15 \%$ permissible relative error, hence, the sample size was 105 cases.

An electrocardiogram (ECG) at presentation was performed in all the patients and the cases were categorized as unstable angina (USA), non-ST elevation MI (NSTEMI) and ST-elevation MI (STEMI) based on the history, ECG changes and cardiac markers. ${ }^{8}$ Fasting serum lipid profile was obtained within 24 hours of hospitalization. Lipid assay was done with Enzymatic Colorimetric Test for TC and TG with lipid Clearing Factor. LDL-C was determined by direct method and HDL-C by precipitation method.

Dyslipidemia was defined based on NCEP ATP III criteria $^{9}$ i.e. any of the following fasting lipid profile values obtained within 24 hours of the event: TC $\geq 200 \mathrm{mg} /$ $\mathrm{dl}, \mathrm{TG} \geq 150 \mathrm{mg} / \mathrm{dl}, \mathrm{LDL} \geq 130 \mathrm{mg} / \mathrm{dl}$, and $\mathrm{HDL} \leq 40$ $\mathrm{mg} / \mathrm{dl}$ or patient already on medication for dyslipidemia. Dyslipidemia was evaluated with age, sex, and other risk factors.

The data were collected and entered in MS-Excel 2007 and analyzed using the Statistical Package for Social Sciences (SPSS) version 20 software.

\section{RESULTS}

Out of 105 patients, $81(77.1 \%)$ were male and 24 $(22.9 \%)$ were female. The mean age was $59.19 \pm 12.69$ years. Sixty-four (61\%) participants had STEMI, 27 (25.7\%) NSTEMI and 14 (13.3\%) USA. Hypertension was present in $35(33.3 \%)$ and was the most frequently observed risk factor followed by diabetes 33 (31.4\%). Twenty-seven $(25.7 \%)$ patients were overweight or obese, 11 (10.5\%) patients were smokers, $5.7 \%$ had a family history of CAD and $4.8 \%$ had a history of significant alcohol consumption (Table 1).

\begin{tabular}{|c|c|c|c|}
\hline Risk factors & $\begin{array}{l}\text { Total } \\
\text { n (\%) }\end{array}$ & $\begin{array}{l}\text { Male } \\
\text { n (\%) }\end{array}$ & $\begin{array}{l}\text { Female } \\
\mathrm{n}(\%)\end{array}$ \\
\hline $\begin{array}{l}\text { Hyperten- } \\
\text { sion) }\end{array}$ & $35(33.3)$ & 25 (30.9) & $10(41.7)$ \\
\hline $\begin{array}{l}\text { Diabetes } \\
\text { mellitus }\end{array}$ & 33 (31.4) & $25(30.9)$ & $8(33.3)$ \\
\hline $\begin{array}{l}\text { Overweight } \\
\text { or obese }\end{array}$ & $27(25.7)$ & $22(27.2)$ & $5(20.8)$ \\
\hline Smoker & $11(10.5)$ & $6(7.4)$ & $5(20.5)$ \\
\hline $\begin{array}{l}\text { Family histo- } \\
\text { ry of CAD }\end{array}$ & $6(5.7)$ & $5(6.2)$ & $1(4.2)$ \\
\hline $\begin{array}{l}\text { Alcohol user } \\
6(5.7)\end{array}$ & $5(4.8)$ & $4(4.9)$ & $1(4.2)$ \\
\hline Total & 105 (100) & $81(77.1)$ & 24 (22.9) \\
\hline
\end{tabular}

$\mathrm{CAD}=$ Coronary Artery Disease

The mean TC, TG, LDL-C and HDL-C among the participants was $183.43 \pm 35.91 \mathrm{mg} / \mathrm{dl}, 140.59 \pm 46.83 \mathrm{mg} /$ $\mathrm{dl}, 109.90 \pm 26.38 \mathrm{mg} / \mathrm{dl}$ and $41.17 \pm 4.78 \mathrm{mg} / \mathrm{dl}$ respectively. Similarly, it was calculated for both males and females separately (Table 2).

\begin{tabular}{|l}
\begin{tabular}{|l} 
Table 2. The pattern of lipid profile in the study \\
population.
\end{tabular} \\
\hline \begin{tabular}{llll|} 
Lipid profile & $\begin{array}{l}\text { Total } \\
\text { (mean } \pm\end{array}$ & $\begin{array}{l}\text { Male (mean } \\
\pm \text { SD) }\end{array}$ & $\begin{array}{l}\text { Female } \\
\text { (mean } \pm \\
\text { SD) }\end{array}$ \\
& SD) & & SD) \\
TC $(\mathrm{mg} / \mathrm{dl})$ & $183.43 \pm$ & $82.14 \pm$ & $187.92 \pm$ \\
& 35.91 & 36.41 & 34.50 \\
TG $(\mathrm{mg} / \mathrm{dl})$ & $140.59 \pm$ & $142.17 \pm$ & $135.25 \pm$ \\
& 46.82 & 50.37 & 32.39 \\
LDL-C $(\mathrm{mg} /$ & $109.90 \pm$ & $107.10 \pm$ & $119.38 \pm$ \\
$\mathrm{dl})$ & 26.37 & 24.26 & 31.24
\end{tabular}
\end{tabular}


Dhungana et al. Prevalence of Dyslipidemia in Patients with Acute Coronary Syndrome Admitted at Tertiary Care Hospital in Nepal...

\begin{tabular}{|llll|} 
HDL-C $(\mathrm{mg} /$ & $41.17 \pm$ & $41.48 \pm$ & $40.12 \pm$ \\
$\mathrm{dl})$ & 4.77 & 4.49 & 5.60 \\
\hline
\end{tabular}

* TC $=$ Total Cholesterol, $\mathrm{TG}=$ Triglycerides, LDL$\mathrm{C}=$ Low Density Lipoprotein Cholesterol, HDL-C = High Density Lipoprotein Cholesterol

Dyslipidemia was present in 51 (48.6\%) patients. Prevalence of dyslipidemia was $14(58.3 \%)$ in female and $37(45.7 \%)$ in male (Figure 1$)$.

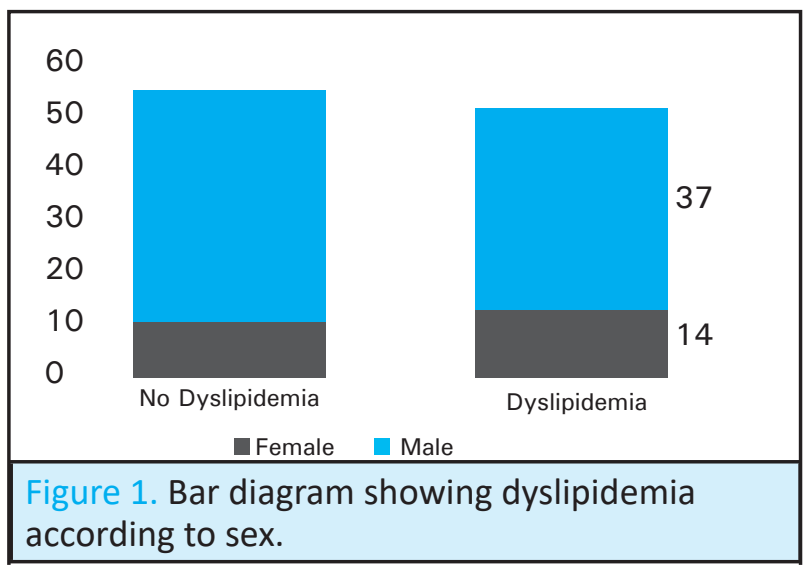

It was more frequent in age group $\leq 45$ years $(58.8 \%)$ than in age group $>45$ years $(46.6 \%)$. Dyslipidemia was present in $9(64.3 \%)$ patients with USA, 13 $(48.1 \%)$ with NSTEMI and $29(45.3 \%)$ with STEMI. Dyslipidemia was present in $8(42.1 \%)$ of underweight (BMI < $18.5 \mathrm{~kg} / \mathrm{m} 2), 24(40.7 \%)$ in normal weight (BMI $18.5-24.9 \mathrm{~kg} / \mathrm{m} 2$ ) and 19 (70.4\%) in overweight and obese patients (BMI $\geq 25 \mathrm{~kg} / \mathrm{m}^{2}$ ). Dyslipidemia was present in 34 (48.6\%) of non-hypertensive and hypertensive patients both, 20 (60.6\%) of diabetic and $31(43.1 \%)$ of non-diabetic patients. Two (33.3\%) of patients with a family history of CAD had dyslipidemia and 49 (49.5\%) of patients without a family history of CAD had dyslipidemia. Dyslipidemia was present in $46(48.9 \%)$ of non-smoker and $5(45.5 \%)$ of smokers whereas it was present in $4(80.0 \%)$ of alcohol consumer and 47 (47.0\%) of patients who did not consume alcohol. Among the diabetic participants, 20 (60.6\%) was found to have dyslipidemia and similarly patients with normal BMI has less percentage of dyslipidemia (Table 3).

\begin{tabular}{|c|c|c|}
\hline Risk factors & No dyslipidemia & Dyslipidemia \\
\hline $\begin{array}{l}\text { No family } \\
\text { history of CAD }\end{array}$ & $50(50.5)$ & $49(49.5)$ \\
\hline $\begin{array}{l}\text { Family history } \\
\text { of } C A D\end{array}$ & $4(66.7)$ & $2(33.3)$ \\
\hline $\begin{array}{l}\text { Non- } \\
\text { hypertensive }\end{array}$ & $36(51.4)$ & $34(48.6)$ \\
\hline
\end{tabular}

\begin{tabular}{|lll|} 
Hypertensive & $18(51.4)$ & $17(48.6)$ \\
Non diabetic & $41(56.9)$ & $31(43.1)$ \\
Diabetic & $13(39.4)$ & $20(60.6)$ \\
Non smoker & $48(51.1)$ & $46(48.9)$ \\
Smoker & $6(54.5)$ & $5(45.5)$ \\
$\begin{array}{l}\text { No history of } \\
\text { alcohol use }\end{array}$ & $53(53.0)$ & $47(47.0)$ \\
$\begin{array}{l}\text { Significant } \\
\text { alcohol } \\
\text { consumer }\end{array}$ & $1(20.0)$ & $4(80.0)$ \\
$\begin{array}{l}\text { Underweight } \\
\text { Normal BMl }\end{array}$ & $11(57.9)$ & $8(42.1)$ \\
$\begin{array}{l}\text { Overweight and } \\
\text { obese }\end{array}$ & $8(29.6)$ & $24(40.7)$ \\
\hline
\end{tabular}

* $\mathrm{CAD}=$ coronary artery disease, $\mathrm{BMI}=$ body mass index

The high serum level of TC was found in 34 (32.4\%), high serum level of TGs in 34 (32.4\%), high serum level of LDL-C in $22(21.0 \%)$ and low serum level of HDL-C in $31(29.5 \%)$ (Table 4$)$.

\begin{tabular}{|c|c|c|c|}
\hline Lipid profile & Categories & $\begin{array}{l}\text { Dyslipid- } \\
\text { emia } \\
\text { n (\%) }\end{array}$ & $\begin{array}{l}\text { Total } \\
\mathrm{n}(\%) \\
\text { TC in } \mathrm{mg} / \mathrm{dl}\end{array}$ \\
\hline \multirow[t]{2}{*}{$\mathrm{TC}$ in $\mathrm{mg} / \mathrm{dl}$} & $<200$ & $17(33.3)$ & 71 (67.6) \\
\hline & $\geq 200$ & $34(66.7)$ & $34(32.4)$ \\
\hline \multirow[t]{2}{*}{$\mathrm{TG}$ in $\mathrm{mg} / \mathrm{dl}$} & $<150$ & 17 (33.3) & 71 (67.6) \\
\hline & $\geq 150$ & $34(66.7)$ & $34(32.4)$ \\
\hline \multirow{2}{*}{$\begin{array}{l}\text { LDL-C in } \\
\mathrm{mg} / \mathrm{dl}\end{array}$} & $<130$ & $29(56.9)$ & $83(79.0)$ \\
\hline & $\geq 130$ & $22(43.1)$ & 22 (21.0) \\
\hline \multirow{2}{*}{$\begin{array}{l}\mathrm{HDL}-\mathrm{C} \text { in } \\
\mathrm{mg} / \mathrm{dl}\end{array}$} & $>40$ & $20(39.2)$ & 74 (70.5) \\
\hline & $\leq 40$ & $31(60.8)$ & 31 (29.5) \\
\hline
\end{tabular}

Abbreviations: TC; total cholesterol, TG; triglycerides, LDL-C; low-density lipoproteins, HDL-C; high-density lipoproteins

The prevalence of high TC, high LDL-C, and low HDL-C were non-significantly high in females and the prevalence of high TG was non-significantly more in males.

\section{DISCUSSION}

This study was conducted to determine the prevalence and pattern of dyslipidemia in patients with ACS from 
a tertiary care hospital in the eastern part of Nepal. In this study, the lipid profile analysis demonstrated the presence of some type of dyslipidemia in $48.6 \%$ of all patients with no significant difference in male and female, with high TC and TG levels being the highest prevalence. Likewise, a study done at the National Heart Centre in $\mathrm{Nepal}^{10}$ found the prevalence of dyslipidemia in $45.5 \%$ of patients with no significant difference between genders.

In this study, the majority of the patients had one or more conventional risk factors for CAD. The common risk factors were dyslipidemia, diabetes, and hypertension which are similar to other studies ${ }^{11,12}$ which demonstrated a high prevalence of one or more major risk factors for CAD and ACS. Majority of patients were male $(77.1 \%)$ suggesting that male gender as one of the risk factors for ACS as seen in previous study. ${ }^{13}$

Dyslipidemia is an independent major risk factor for CAD. Studies have reported a higher prevalence of dyslipidemia among Asians compared to the western population. ${ }^{14}$ A combination of low HDL-C and high TG referred to as atherogenic dyslipidemia, have been implicated as important predictors of CAD. ${ }^{15,16}$

In this study, the most commonly observed lipid abnormality was high TC and TG followed by low HDL-C and high LDL-C. Previous studies on CAD patients also found similar results regarding the presence of high levels of TC, LDL-C, and TG and low levels of HDL-C. ${ }^{17}$, 18 The lower prevalence of high LDL-C as compared to other fractions is consistent with previous study ${ }^{14}$ which showed a higher prevalence of low LDL levels among Asians. Our study showed low HDL-C levels in a high percentage of patients $(60.8 \%)$ as shown in the previous study which revealed that South Asians had lower HDL-C levels than rest of the other population. ${ }^{14}$
These findings may have clinical importance since the prior study in patients with CAD who had a low HDL-C was associated with increased risk for death and $\mathrm{MI}$, even among patients achieved LDL $<70 \mathrm{mg} / \mathrm{dl}{ }^{19}$

We assessed the effect of other major risk factors of CAD on the prevalence of dyslipidemia. We did not find a significant difference in the prevalence of dyslipidemia among those with or without major risk factors except for obese or overweight patients who had a higher burden of dyslipidemia similar to a previous study showing that BMI and central obesity is associated with atherogenic dyslipidemia. ${ }^{20}$

This study provides the pattern of lipid abnormalities early after ACS among the Nepalese population and guides to the early classification of dyslipidemia and the selection of lipid-lowering therapy. This is a hospital-based study in a small number of patients. Lipid profile was obtained within the first 24 hours of the event and baseline values were not available for comparison. We did not look at the apolipoprotein measures (Apo B and Apo Al) which are strongly associated with the risk of $\mathrm{MI}$ in South Asians.

\section{CONCLUSIONS}

There is a lower prevalence of high LDL-C and a high prevalence of lower HDL-C levels among the Nepalese population. Although Nepalese patients are likely to benefit from lowering LDL-C, the threshold for treatment and targets seem to be lower. These thresholds and targets need to be determined by large studies and by our guidelines. Given the lower levels of HDL-C, approaches to increase the HDL-C may be helpful in our population.

Conflict of Interest: None.

\section{REFERENCES}

1. Lee JS, Chang PY, Zhang Y, Kizer JR, Best LG, Howard BV. Triglyceride and HDL-C Dyslipidemia and Risks of Coronary Heart Disease and Ischemic Stroke by Glycemic Dysregulation Status: The Strong Heart Study. Diabetes Care. 2017 Apr;40(4):529-37. [PubMed | Full Text | DOI]

2. Yusuf S, Hawken S, Ounpuu S, Dans T, Avezum A, Lanas $\mathrm{F}$, et al. Effect of potentially modifiable risk factors associated with myocardial infarction in 52 countries (the INTERHEART study): a case-control study. Lancet. 2004 Sep 11-17;364(9438):937-52. [PubMed | Full Text | DOI]
3. Montalescot G, Dallongeville J, Van Belle E, Rouanet S, Baulac C, Degrandsart A, et al. OPERA Investigators. STEMI and NSTEMI: are they so different? 1-year outcomes in acute myocardial infarction as defined by the ESC/ ACC definition (the OPERA registry). Eur Heart J. 2007 Jun;28(12):1409-17. [ $\underline{\text { PubMed }}|\underline{\text { FullText }}| \underline{\text { DOI }}$

4. Gore JM, Goldberg RJ, Matsumoto AS, Castelli WP, McNamara PM, Dalen JE. Validity of serum total cholesterol level obtained within 24 hours of acute myocardial infarction. Am J Cardiol. 1984 Oct 1;54(7):722-5. [PubMed | Full Text | $\underline{\mathrm{DOI}}]$ 
5. Carlsson R, Lindberg G, Westin L, Israelsson B. Serum lipids four weeks after acute myocardial infarction are a valid basis for lipid-lowering intervention in patients receiving thrombolysis. Br Heart J. 1995 Jul;74(1):18-20. [ㄹuMed |

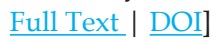

6. Antman EM, Hand M, Armstrong PW, Bates ER, Green LA, Halasyamani LK, et al. 2007 focused update of the ACC/ AHA 2004 guidelines for the management of patients with ST-elevation myocardial infarction. A report of the American College of Cardiology/ American Heart Association Task Force on Practice Guidelines. Circulation. 2008 Jan 15;117(2):296-329. [PubMed | Full Text | DOI]

7. Khatri P, Simkhada R. Study of conventional risk factors in acute coronary syndrome. Journal of universal college of medical sciences. 2016 Jan11;3(2):1-4. [ Full Text | DOI]

8. Findlay IN, Cunningham AD. Definition of acute coronary syndrome. Heart. 2005 Jul;91(7):857-9. [마bMed | Full Text | $\underline{\mathrm{DOI}}]$

9. National Cholesterol Education Program (NCEP) Expert Panel on Detection, Evaluation, and Treatment of High Blood Cholesterol in Adults (Adult Treatment Panel III). Third Report of the National Cholesterol Education Program (NCEP) Expert Panel on Detection, Evaluation, and Treatment of High Blood Cholesterol in Adults (Adult Treatment Panel III) final report. Circulation. 2002 Dec 17;106(25):3143-421. [PubMed | Full Text | DOI]

10. Adhikari CM, Prajapati D, Baniya B, Regmi S, Bogati A, Thapaliya S. Prevalence of Conventional Risk Factors in ST-Segment Elevation Myocardial Infarction Patients in Shahid Gangalal National Heart Centre, Nepal. J Nepal Med Assoc. 2014 Sept;52(195):914-9. [PubMed | FullText | DOI]

11. Greenland P, Knoll MD, Stamler J, Neaton JD, Dyer AR, Garside DB, et al. Major risk factors as antecedents of fatal and nonfatal coronary heart disease events. JAMA. 2003 Aug 20;290(7):891-7. [PubMed | Full Text | DOI]
12. Khot UN, Khot MB, Bajzer CT, Sapp SK, Ohman EM, Brener SJ, et al. Prevalence of conventional risk factors in patients with coronary heart disease. JAMA. 2003 Aug 20;290(7):898-904. [PubMed | Full Text | DOI]

13. Yusufali AM, AlMahmeed W, Tabatabai S, Rao K, Binbrek A. Acute coronary syndrome registry from four large centers in United Arab Emirates (UAE-ACS Registry). Heart Asia. 2010 Oct 5;2(1):118-21. [ $\underline{\text { PubMed }}|\underline{\text { Full Text }}| \underline{\text { DOI] }}$

14. Karthikeyan G, Teo KK, Islam S, McQueen MJ, Pais P, Wang $\mathrm{X}$, et al. Lipid profile, plasma apolipoproteins, and risk of a first myocardial infarction among Asians: An analysis from the INTERHEART Study. J Am Coll Cardiol. 2009 Jan 20;53(3):244-53. [uuㄹed | Full Text | DOI]

15. Harchaoui KE, Visser ME, Kastelein JJ, Stroes ES, Dallinga-Thie GM. Triglycerides and cardiovascular risk. Curr Cardiol Rev. 2009 Aug;5(3):216-22. [PubMed | Full Text $\mid \underline{D O I}]$

16. Amarenco P, Labreuche J, Touboul PJ. High-density lipoprotein-cholesterol and risk of stroke and carotid atherosclerosis: A systematic review. Atherosclerosis. 2008 Feb;196(2):489-96. [PubMed | Full Text | DOI]

17. Piegas LS, Avezum A, Pereira JCR, Rossi Neto JM, Hoepfner C, Farran JA, et al. Risk factors for myocardial infarction in Brazil. Am Heart J. 2003 Aug;146(2):331-8. [ $\underline{\text { PubMed | Full }}$ Text $\mid \underline{D O I}]$

18. Avezum A, Piegas LS, Pereira JCR. Risk Factors Associated With Acute Myocardial Infarction in the São Paulo Metropolitan Region. A Developed Region in a Developing Country. Arq Bras Cardiol. 2005 Mar;84(3):206-13. [PubMed | Full Text | DOI]

19. Barter P, Gotto AM, LaRosa JC, Maroni J, Szarek M, Grundy SM, et al. HDL cholesterol, very low levels of LDL cholesterol, and cardiovascular events. N Engl J Med. 2007 Sep 27;357(13):1301-10. [라Med | Full Text | DOI]

20. Micah FB, Nkum BC. Lipid disorders in hospital attendants in Kumasi, Ghana. Ghana Med J. 2012 Mar;46:14-21. [PubMed | Full Text] 